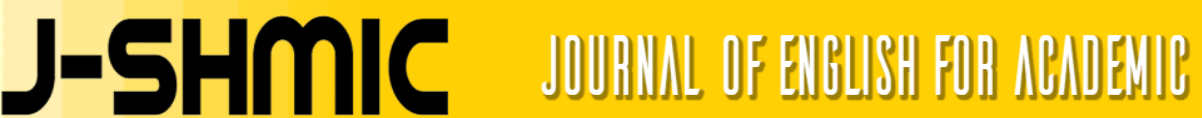

\section{Improving Students' Tenses Mastery through Tenses Symbol Technique (TST) in Class X4 at SMA Negeri 1 Pekanbaru}

\author{
Khairunnisah \\ SMA Negeri 1 Pekanbaru \\ email: khairunnisah.Usman@gmail.com
}

\begin{abstract}
Student's Tenses mastery is an important competence to support the major English skills, listening, speaking, reading, and writing. Beside, the tenses mastery is also important to have another grammar materials that need Tenses mastery as the basic knowledge. However, in reality, students' tenses mastery is very minimal that they are not able to call out the names of the tenses, mention the formulas, let alone to understand meaning and the usage in sentences. To solve this problem the resercher has created a teaching technique, namely, Tenses Symbols Technique (TST) that covers four steps of tenses mastery: memorizing tenses names, formulating tenses patterns, understanding tenses meanings, dan applying in context. Clasroom Action Research is the research method applied in this research because the aim of this research merely to solve the problem the researcher has in her own class. From the two cycles of Classroom Action Research that consists of planning, acting, observing, and reflecting, and from data analyzing, it was proven that Tenses Symbols Tecnique (TST) could improve the students' tenses mastery as $81 \%$ in cycle 1 and $95 \%$ in cycle 2 because the application of symbols in this technique could simplify of the process of decoding the meaning of each tenses. So, the result of this research is TST could improve students' tenses mastery.
\end{abstract}

Key words : Student's tenses mastery

\section{Meningkatkan Penguasaan Tenses Simbol Teknik (TST) di Kelas X4 SMA Negeri 1 Pekanbaru}

\section{Abstrak}

Penguasaan Tenses pada siswa merupakan pengetahuan yang sangat penting baik untuk mendukung keterampilan mendengar, berbicara, membaca, dan menulis. Disamping penguasaan Tenses adalah kemampuan dasar yang harus dimiliki siswa untuk mempelajari materi-materi grammar yang lain yang berkaitan dengan penguasaan Tenses. Namun masalah di lapangan adalah siswa memiliki pengetahuan Tenses yang sangat minim dimana mereka tidak mampu menyebutkan nama-nama Tenses, menyebutkan rumus-rumusnya, apalagi mengerti makna dan penggunaannya dalam kalimat.Untuk itu peneliti menciptakan suatu technique penguasaan tenses yang diberi nama Tenses Symbols Technique (TST), yang meliputi 4 langkah yaitu; memorizing tenses names, formulating tenses patterns, understanding tenses meanings, dan applying in context. Penelitian Tindakan Kelas merupakan metode yang digunakan dalam 
penelitian ini karena hakikat penelitian ini adalah untuk memperbaiki masalah yang dihadapi peneliti sebagai seorang guru di dalam kelasnya sendiri. Dari dua siklus pengajaran yang terdiri dari tindakan merencanakan pengajaran (planning \& revising), melaksanakan proses belajar mengajar (acting), melakukan observasi (observing), dan merefleksikan hasil pengajaran (reflecting), dan dari instrument penelitian didapat hasil penelitian yaitu Tenses Symbols Technique (TST) dapat meningkatkan penguasaan Tenses siswa mencapai $81 \%$ pada siklus 1 dan $95 \%$ pada siklus 2 karena faktor-faktor penggunaan symbol dalam TST yang mempermudah proses decoding dan pemaknaan pada siswa.Jadi hasil penelitian ini adalah bahwa Tenses Symbols Technique (TST) dapat digunakan untuk meningkatkan penguasaan tenses siswa.

Kata Kunci : Penguasaan Tenses Siswa

\section{INTRODUCTION}

Tenses knowledge, as the main knowledge in English grammar by which sentences can be built up, by which variety of sentence formation can be formed, or by which jumbled words can be arranged orderly does not get an appropriate attention in EFL syllabus. In the previous curriculum mandated in Indonesia (KTSP), there is no material that aims the students to be able to master grammar, morever, tenses. The mastering of text types was the most focus, instead.

On the other hand, the need to master Tenses knowledge among students does not show the similar tendency. Supposed if the curriculum aims students to be able to write a type of the text correctly, students couldn't do it due to lack of grammar knowledge, especially, Tenses. Or when the students want to speak and already know what to speak, but when they are speaking, their accuracy is minimal because they do not know how to organize the sentences well. It is also happened when the students need to listen or to read a text where the information provided can not be comprehended maximally because their grammar knowledge is not available to lead them to understanding. Refering to what Thornbury (2002) said that grammar is a "sentence-making machine". It means that, even though one has sufficient number of vocabulary, without having good grammar mastery, he will find problem in arranging those vocabularies into good sentences. As what is said by Ur (2006), one cannot use words unless he/she knows how those words should be put. Therefore, it can't be denied that Grammar teaching, especially Tenses mastery is very important in EFL class not only as a knowledge of sentence rules, but also as the base of communication where understanding to sentences is acquired.

As long as my experience being a teacher, Tenses is an easy material to be taught, but hard to understand. It is easy in the part of teachers because we only teach the rules that are already provided, drill them with the pattern and ask them to apply the same formula to the sentences that is formally arranged by 
us (teachers). In this respect, Gokhale (2010) claims that in most cases, grammar is taught as an end in itself rather than as a means to an end. Ideally, the teaching of grammar must help our students to produce utterances that exemplify the grammatical rules, but it seems that generally the teacher focuses on teaching the rules of grammar and ignores the communicative aspect of language. This can cause boredom among students and disability of understanding.

In part of students, it is quite difficult to be studied since there are so many technical terms in Tenses that should be recognized, beside the complicated formulas that are almost the same to each other that students should memorize and apply to their sentences. The technical terms such as Tenses, Perfect, Progressive, Continous, and so on will be hard to memorize. These technical terms, then become more complicated if they are mixed to refer to kinds of time sequences.

The interference of mother tongue, Indonesian language, is also identified as the cause of the difficulties of Tenses mastery. Indonesian language is a language that doesn't have Tenses system where all the verbs are used in all time sequences. Someone says, "Saya sedang belajar sekarang" (I am studying now), has the same meaning with "Saya belajar sekarang" (I study). For both sentences in English, there is significant difference between Simple Present Tense and Present Continous Tense that affects the meaning as a whole that in Indonesian language it doesn't distinguish anything. Therefore, the tenses system in English is quite confusing for mostly Indonesian students.

Concerning the problems stated above Harmer (2007:137) said that there are three groups of grammatical mistakes. Two of them are "slips", and "errors". When it is a "slip", students usually understand that they have made a mistake and are therefore able to correct themselves. On the other hand, „Errors"e require correction and explanation as learners do not have the language knowledge needed to correct these types of mistakes yet. In this case, Indonesian students might have both of the grammatical mistakes. They might already know the rules, but they 'slip' when applying them, or they do 'errors' because of misconception of the grammatical knowledge. In order to correct them there should be a practical method that can make students easily memorize the technical terms as well as apply them correctly in their sentences.

As a teacher, I think I should solve this problem because this is my responsibility to help my students to be more aware of the knowledge that is actually very important for them, that is the knowledge of Tenses. I should find a wayout that can make my students do not do any 'slips' or 'errors' especially when using Tenses.

After sufficient teaching experiments, I have found that teaching Tenses by using Tenses Symbols that I create myself could improve the students' ability in Tenses Mastery. According to Salomon (1977) to summarize, the symbol systems of media affect the acquisition of knowledge in a number of ways. First, they highlight different 
aspects of content. Second, they vary respect to ease of recoding. Third, specific coding elements can save the learner from difficult mental elaborations by overtly supplanting or short-circuiting specific elaboration. Fourth, symbol systems differ with respect to how much processing they demand or allow. Fifth, symbol system differ with respect to the kinds of mental processes they call on for recording and elaboration. Thus, symbol systems partly determine who will acquire how much knowledge from what kinds of messages. (p.226227). In short, it can conclude that by using symbols to teach Tenses, students could get many advantages of the simplification that symbols can do as a media of teaching as they can include so many information just in simple symbol that represent them.

Based on the discussion above, I have identified the problems that my students experience related to Tenses mastery. Firstly, they find it very difficult to memorize the technical terminologies and the complicated formulas used in Tenses rules due to the inexistence of Tenses system in mother tongue, in this case Indonesian language. This is affecting their performance in the four major skills, writing, speaking, reading, and listening. Secondly, my students frequently do 'slips' and 'errors' in applying Tenses rules in their sentences that need to be improved. Therefore, there should be an effective method to teach them Tenses.

The purpose of this research is to investigate whether the Tenses symbols Technique(TST) created by the researcher is effective to solve the problems of students' difficulties in memorizing the technical terminologies and the formulas used in Tenses rules and to what extent the Tenses symbols as media of teaching can improve the students' Tenses mastery.

The importance of the research is mainly for the students to improve their ability in Tenses mastery so that theirr performance in the four major skills, writing, speaking, reading, and listening will be better. By using Symbols of Tenses as the media of teaching, students will memorize the technical terms and Tenses formula easily so that they can apply them in their sentences correctly.

For teachers, the using of Tenses Symbols is expected to be an alternative technique of teaching that can motivate students to study Tenses and reduce their boredom of studying formal rules of conventional teaching.

For other researchers, it is hoped that this research will enrich the teaching techniques that have ever existed in EFL study. And, I am as the creator of this technique realize that this technique is far from perfection that I invite for other researchers to investigate this technique more deeply to get more advantages from it.

The Tenses Symbols Technique as I stated before is created by me myself as the result of sufficient teaching experiments and a deep thinking in the purpose of solving the difficulties in students' Tenses mastery. This is in line with what Deacon, T.W. (1997) cited that human is called a symbolic species, the creative and flexible use of a vast array of different types of symbols is unique to humans. The emergence in 
evolution of the symbolic capacity irrevocably transformed our species (Corballis, M.C. 1999), vastly expanding our intellectual horizons and making possible the cultural transmission of knowledge to succeeding generations (Vygotsky, L.1962). These are to say that the use of symbols to transfer information, knowledge, and culture in human is very natural and it is as old as the history of human itself.

Symbols is defined as something that someone intends to represent something other than itself (DeLoache, J.S. 2002). Symbols are general. It means that the very indefinite term 'something' is quite deliberately in the above definition to emphasize that virtually anything can be used to represent virtually anything else: spoken words, printed words, pictures, video images, numbers, graphs, a block of wood, a chair in a store window, maps, and an infinite list of other possibilities can be exploited to stand for something that someone wants to symbolize. In this case, tenses symbols in the form of arrows, circles, dashes, and lines will represent the tenses both the names and the formulas of the 12 tenses. By using these symbols the process of memorizing, understanding, and applying will be done more easily.

The word 'Tense' is derived from Latin word 'Tempus' meaning 'Time'(Lyon,1995). It means that traditionally, the Tense is defined as the term of time. In practice, English is indeed a language that specify every events according to when it is happened. It means that different from Indonesian language, English has a much more structured time division that when we want to compose a text or utter an expression, we should concern the Tenses of the sentences if not we will make errors in meaning or miss information, instead.

Furthermore, Sidney Greenbaum (1990) defines Tense as grammatical category that is realized as verb inflection. The inflection of the verbs indicates the changing of the Tense. Verb that is positioned as the predicate in a sentence is the key to determine the Tense of the sentence. It is in line with Graver (1986,p.50) who said that the term "tense" is used to refer to a verb form, not to chronological time. English verbs are used to express the aspect (simple, continuous or perfect) of an action or event. To some linguists, structurally speaking, there are two main tenses; present and past. Future is included in the present. On the other hand, most of the linguists state that there are three tenses in English; present, past and future. Here, we find that there are two grammatical terms we should notice in the discussion of Tenses mastery; Tenses and aspects which both of them are different but closely related.

Based on the theories stated above, I can draw conclusion that the term of Tenses cover two aspects; Tenses ( present, past, and future) and Aspects ( simple, continous, and perfect). In Tenses teaching, we recognize the combination of the two categories. The Present Tenses are; simple present, present continous, present perfect, The Past Tenses are simple past, Past Continous, and Past Perfect, and The Future Tenses are simple future, Future Continous, and Future Perfect. While the 
combination of Perfect and Continous, we have Present perfect continous, Past perfect continous, and Future Perfect continous. So, there are 12 Tenses will be being discussed in this research paper.

The indicators of Tenses mastery used in this research is based on what Nunan (2003) argues that tenses will be mastered if the students are able to memorize, understand, and apply the tenses rules in their communicative activities. Memorizing is important to do since there are many technical terms and complicated formulas in Tenses that might be strange for most students whose mother tongue doesn't have tenses system. While understanding is the main goal by which students can apply the tenses rules in communication orally or in written.

The Tenses Symbols Technique as I stated before is created by me myself as the result of sufficient teaching experiments and a deep thinking in the purpose of solving the difficulties in students' Tenses mastery. This is in line with what Deacon, T.W. (1997) cited that human is called a symbolic species, the creative and flexible use of a vast array of different types of symbols is unique to humans. The emergence in evolution of the symbolic capacity irrevocably transformed our species (Corballis, M.C. 1999), vastly expanding our intellectual horizons and making possible the cultural transmission of knowledge to succeeding generations (Vygotsky, L.1962). These are to say that the use of symbols to transfer information, knowledge, and culture in human is very natural and it is as old as the history of human itself.
Symbols is defined as something that someone intends to represent something other than itself (DeLoache, J.S. 2002). Symbols are general. It means that the very indefinite term 'something' is quite deliberately in the above definition to emphasize that virtually anything can be used to represent virtually anything else: spoken words, printed words, pictures, video images, numbers, graphs, a block of wood, a chair in a store window, maps, and an infinite list of other possibilities can be exploited to stand for something that someone wants to symbolize. In this case, tenses symbols in the form of arrows, circles, dashes, and lines will represent the tenses both the names and the formulas of the 12 tenses. By using these symbols the process of memorizing, understanding, and applying will be done more easily.

There are 12 tenses will be represented by the tenses symbols; The Present Tenses are; Simple Present, Present Continous, Present Perfect, and Present Perfect Continous, The Past Tenses are simple past, Past Continous, Past Perfect, and Past Perfect Continous, and The Future Tenses are Simple Future, Future Continous, Future Perect and Future Perfect Continous. While the combination of Perfect and Continous, we have Present perfect continous, Past perfect continous, and Future Perfect continous.

1. The Basic symbols are;

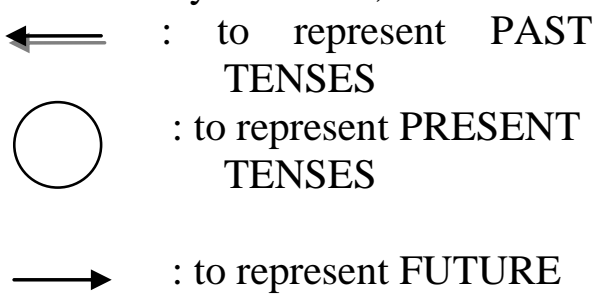

Improving Students' Tenses Mastery Through Tenses Symbol Technique (Tst) In Class X4 At Sma Negeri 1 Pekanbaru 


\section{TENSES}

2. The Aspects symbols are;

- $\quad$ : to represent SIMPLE

------- $\quad$ : to represent

CONTINOUS

$\longrightarrow \mid \quad$ :to represent PERFECT

\begin{tabular}{l|l} 
: to represent PERFECT \\
CONTINOUS
\end{tabular}

3. The Tenses Symbols are;

A. THE PAST TENSES

$\longleftarrow \quad$ : to represent SIMPLE

PAST TENSE

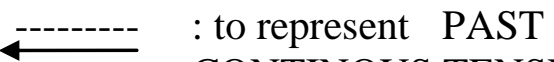

CONTINOUS TENSE

$\rightleftarrows \quad \begin{aligned} & : \text { to represent PAST } \\ & \text { PERFECT TENSE }\end{aligned}$

----- : to represent PAST

PERFECT

CONTINOUS

TENSE

\section{B. THE PRESENT TENSES}

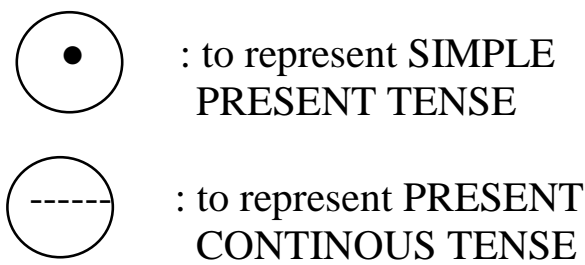

$\longrightarrow$ : to represent PRESENT

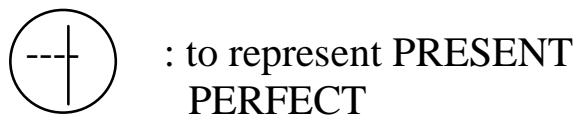

CONTINOUS TENSE

C. THE FUTURE TENSES

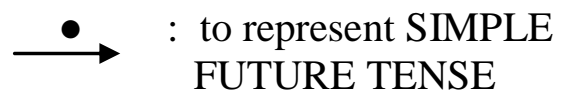

$\stackrel{-\cdots}{\longrightarrow} \quad$ to represent FUTURE

CONTINOUS TENSE

$\Longrightarrow$ : to representFUTURE

PERFECT TENSE

$\stackrel{-----}{\longrightarrow}$ : to represent FUTURE

PERFECT

CONTINOUS TENSE

\section{a. The steps in Tenses Symbol Teaching}

The steps should be followed in teaching Tenses Symbols are:

1. Memorizing the names of the symbols

Here, the students are introduced to the names of the basic symbols, the aspects symbols, and the combination between them. Drilling orally without allowing the students to write the names of the symbols is the best way to do that because it will make them spontanously recognize the visual of the tenses. This is done several times until all students can say the names fluently.

\section{Formulating the symbols}

This is the step which is done by exposing the students with the formula of each tenses. Verb inflection is the most focus in this step. The students are asked to memorize the verb inflections as the followings:

\section{A. THE PAST TENSES}

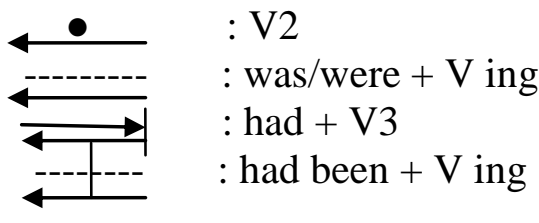

B. THE PRESENT TENSES

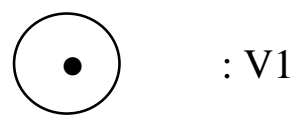

Improving Students' Tenses Mastery Through Tenses Symbol Technique (Tst) In Class X4 At Sma Negeri 1 Pekanbaru 


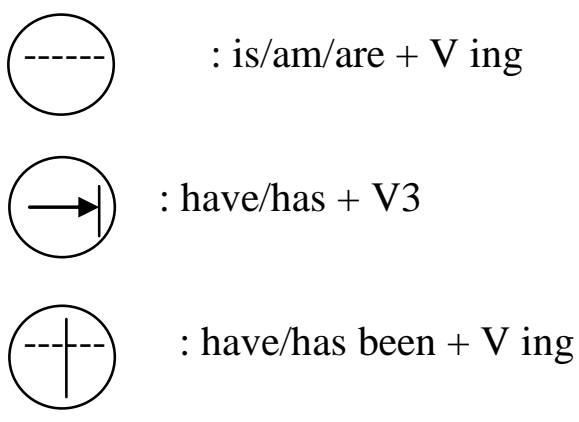

C. THE FUTURE TENSES

$$
\begin{aligned}
& \stackrel{\text { • }}{\longrightarrow} \text { will + V1 } \\
& \stackrel{----}{\longrightarrow}: \text { will be }+\mathrm{V} \text { ing } \\
& \Longrightarrow \text { : will have }+ \text { V } 3 \\
& \stackrel{-----}{\longrightarrow} \text { : will have been }+\mathrm{V} \text { ing }
\end{aligned}
$$

It's better in doing this step, students also are not allowed to write or record the formulas in order to make them memorize the formula authomatically.

\section{Understanding the symbols}

To understand the symbols, the students are given to short, and simple explanation of each symbols and their meanings.

The meanings of The Tenses Symbols

1. The Basic symbols

$$
\begin{gathered}
\text { : means PAST, LAST ...., } \\
\ldots . \text { AGO, etc } \\
\text { : means PRESENT, NOW, } \\
\text { TODAY, etc } \\
\text { : means FUTURE, NEXT } \\
\ldots ., \text { TOMORROW, etc. }
\end{gathered}
$$

2. The Aspects symbols

- $\quad$ : means ENDED IN ...

$$
\text { -------- : means OVER TIME IN }
$$

J-SHMIC, Vol 5, No 1, February 2018

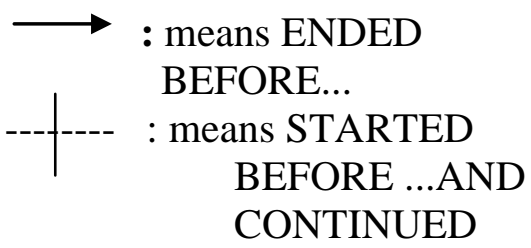

3. The Tenses Symbols

A. THE PAST TENSES

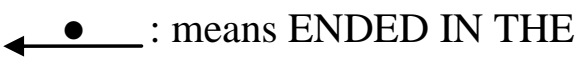
PAST

: means OVER TIME IN THE PAST

$\rightleftarrows$ :means ENDED

BEFORE PAST TIME

---1-- : means STARTED

BEFORE PAST AND

CONTINUED

B. THE PRESENT TENSES
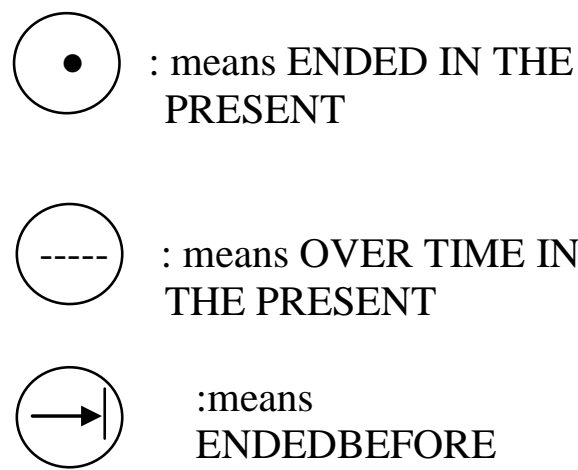

:means

ENDEDBEFORE PRESENT

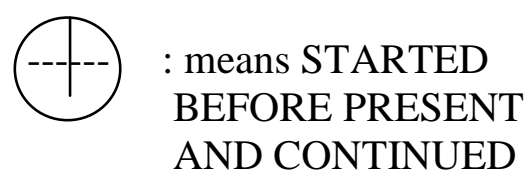

C. THE FUTURE TENSES

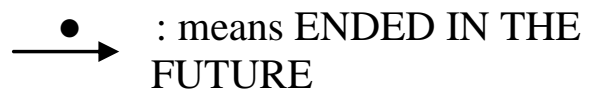

$\stackrel{----}{\longrightarrow}$ : means OVER TIME IN THE FUTURE

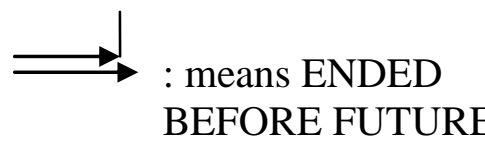

Improving Students' Tenses Mastery Through Tenses Symbol Technique (Tst) In Class X4 At Sma Negeri 1 Pekanbaru 


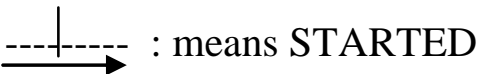 BEFORE FUTURE AND CONTINUED}

\section{4. applying Tenses in context}

After being certaint of students' understanding, the next step is to apply the formulas to the sentences. It can be done by asking them to change verbs in brackets into the suitable forms of the verbs in a single sentence or by giving them a text in which they can decide which tense will macth the given context.

As stated by Salomon (1977) using symbols in learning process has some significant advantages; to summarize, the symbol systems of media affect the acquisition of knowledge in a number of ways. First, they highlight different aspects of content. Second, they vary respect to ease of recoding. Third, specific coding elements can save the learner from difficult mental elaborations by overtly supplanting or short-circuiting specific elaboration. Fourth, symbol systems differ with respect to how much processing they demand or allow. Fifth, symbol system differ with respect to the kinds of mental processes they call on for recoding and elaboration.

In line with this Marqulies ( ) also cited that using symbols make ideas become more visible, help communication, record ideas, and engage experience more memorable. As proposed by D. Hyerle (1996) "The use of visual tools creates a shift in classroom dynamics from passive to interactive learning for all to see." In conclusion, it is very beneficial using symbols in the process of teaching and learning due to the mental processes happened while the learning process in which the learners will be able to visualize the principle concepts to be planted in the students, in this case tenses mastery.

There are many researches have been done on the use of symbols in language learning assistant. Researchers have explored the use of language and symbols (signs and drawings) by students in the process of reasoning (Robotti, 2002; Radford, 2001). Judy S. DeLoache (University of Virginia, Psychology Department, 2004) in his paper "Becoming symbol-minded" has found that using symbols is very useful in children learning due to the relation

between symbolic objects and their referents and using those relations to acquire information. What we have been learning about symbolic development in the first years of life has important practical implications, such as how to tailor educational materials to children's fledgling symbolic skills (Uttal, D.H. et al. 1999).

\section{b. The Advantages of using Symbols}

As stated by Salomon (1977) using symbols in learning process has some significant advantages; to summarize, the symbol systems of media affect the acquisition of knowledge in a number of ways. First, they highlight different aspects of content. Second, they vary respect to ease of recoding. Third, specific coding elements can save the learner from difficult mental elaborations by overtly supplanting or short-circuiting specific elaboration. Fourth, symbol systems differ with respect to how much processing they demand or 
allow. Fifth, symbol system differ with respect to the kinds of mental processes they call on for recoding and elaboration.

In line with this Marqulies also cited that using symbols make ideas become more visible, help communication, record ideas, and engage experience more memorable. As proposed by D. Hyerle (1996) "The use of visual tools creates a shift in classroom dynamics from passive to interactive learning for all to see." In conclusion, it is very beneficial using symbols in the process of teaching and learning due to the mental processes happened while the learning process in which the learners will be able to visualize the principle concepts to be planted in the students, in this case tenses mastery.

\section{METHOD}

The participants/subjects of this research are the students of the second semester of class $X$ at SMAN 1 Pekanbaru. There are 33 students in this class who will be investigated. This is the class in which the speaking problems has been identified and need solutions.

The test will be used to measure the tenses mastery of the students in this research is writing test especially in the applying the tenses step (the fourth step). The writing test is assumed will be more suitable since the grammar rules are applied mostly in written text.

Tenses mastery is the stuff will be tested in this research that covers the mastery of the twelve tenses in English; The Present Tenses are; Simple Present, Present Continous, Present Perfect, and Present Perfect Continous, The Past Tenses are simple past, Past Continous, Past Perfect, and Past Perfect Continous, and The Future Tenses are Simple Future, Future Continous, Future Perect and Future Perfect Continous. While the combination of Perfect and Continous, we have Present perfect continous, Past perfect continous, and Future Perfect continous.

The indicators will be used is as suggested by Nunan (2003) that tenses will be mastered if the students are able to memorize, understand, and apply the tenses rules in their communicative activities. The following table shows the relation between the variable to be tested and its indicators:

Table 1. Indicators of Tenses Mastery (Nunan, 2003)

\begin{tabular}{|l|l|l|l|}
\hline No & $\begin{array}{l}\text { Variable to be } \\
\text { tested }\end{array}$ & Indicators & Sub-indicators \\
\hline 1 & $\begin{array}{l}\text { Students Tenses } \\
\text { Mastery }\end{array}$ & Memorize/ & - Memorize the tenses names \\
\cline { 4 - 5 } & & $\begin{array}{l}\text { Formulate the } \\
\text { tenses }\end{array}$ & $\begin{array}{l}\text { - Memorize the formulas of } \\
\text { the tenses }\end{array}$ \\
\cline { 4 - 5 } & $\begin{array}{l}\text { Understand the } \\
\text { tenses }\end{array}$ & $\begin{array}{l}\text { - Understand the three basic } \\
\text { tenses (past, present, and } \\
\text { future) } \\
\text { - Understand the aspects }\end{array}$ \\
\hline
\end{tabular}




\begin{tabular}{|l|l|l|l|}
\hline \multicolumn{1}{|l|}{} & & $\begin{array}{l}\text { (simple, continous, perfect, } \\
\text { and perfect continous) }\end{array}$ \\
\hline 4 & $\begin{array}{l}\text { Apply } \\
\text { communicatively } \\
\text { in written form. }\end{array}$ & $\begin{array}{l}\text { - Apply the tenses in a } \\
\text { sentence. } \\
\text { - Apply the tenses in vary of } \\
\text { texts }\end{array}$ \\
\hline
\end{tabular}

Having a one and half month research a the class X4 of SMAN 1 Pekanbaru, the required data that lead to the significant findings, have been found and here is the description and the analysis of them.

1. The first step of memorizing the symbols then continued by combining the basics and the aspects that become the 12 tenses; simple past tense, past continues tense, past perfect, past perfect continues, simple present, present continues, present perfect, present perfect continues, simple future, future continues, future perfect, future perfect continues. This was also done easily by the students that they looked enjoy and unstressful even the teacher drilled them by jumbling the order of the symbols. The drilling was done in faster and faster tempo to make the students authomatically recognize the symbols whenever they see them.

\section{The second step of formulating} the symbols then was started by focusing on the inflection of each tenses that is by only focusing on the predicate (verb forms) without mentioning the subjects or objects of the sentence patterns. It is to symplify the process of decoding by only have a short form to remember. When the teacher pointed one symbol the students directy called the formula of the predicate and so on. This was also not difficult for the students to do comparing with the conventional technique that to memorize the formula of the tenses, the students should mention the complete formula of subject, predicate, object, or complement that need more time and boredom among students.

After some drilling of the class, the teacher then tested the students to mention the names of the symbols and their formula one by one in front of the class. In doing this the teacher took a sample of the low students to test them whether they had already memorized the names as well as the formula of the symbols or not. It was done succesfuly that without any obstacles one by one students mentioned the names and the formula of the symbols fluently. Because of time limit, only five students who got turns while to have more vivid data, the teacher gave written test that asked students to draw the symbols based on the sentences given.

3. The step of understanding then was continued at the second meeting. After some review, the teacher displayed the symbols of the 12 tenses and mentioned the meaning of each symbols. When in conventional way, the teacher explains the meaning of the tenses in long explanation, in TST the meaning of the tenses is given shortly and simple by exposing the use of verbs and prepositions such as, ended in, over time, etc. as 
explained in Chapter 2 of this paper. It was also easy for students to comprehend because the two verb words can cover the general meaning of each tenses, past tenses, present tenses, and future tenses. To make sure that the students had understood the meaning of the tenses, the teacher gave a written test containing a text with the use of some tenses. The students were asked to rewrite the text in their own words explaining the meaning of each sentences in the text. This was done half of the period.

4. For the rest of the half period, the final step of applying the tenses was begun. Here, the students were asked to continue a sentence with certain tenses to become a complete text that by concerning the formula of the sentence given, students should know in what tense they should write. Below is the table of students' test result in the four steps of TST;

\section{FINDINGS AND DISCUSSION}

\subsection{Description of Data Analysis}

There are two types of data got in this research; qualitative data and quantitative data. Both of the two kinds were taken by using such kinds of instruments and the data being taken will match the purpose of the research and will solve the problem of learning Englih tenses for the students.

The qualitative data was taken by using observation check list that consists of indicators that are based on the appropriate theories, besides using field notes and interview; in this case they are not formatted because of the nature of flexibility of situation in the field. On the other hand, the quantitative data, as it is counted in number, was formatted in the form of score rubric that the scale is also based on the indicators defined in theories.

Tenses Symbols Technique (TST) that is assumed could solve the problem of difficulties in tenses mastery was employed in this reserach in which the four stages in this technique; memorizing, formulating, understanding, and applying the tenses were experimented in class X4 of SMAN 1 Pekanbaru to proof the assumption. Each of the four stages was observed in three cycles of Action Research that each cycle was done in three meetings or 6 hours of teaching and learning process. After gathering all the data, it was analyzed qualitatively by following the steps suggested by Gay (2000) as well as quantitatively that is by scoring students' performances in speaking by numbers.

The first cycle was started by designing a lesson plan for the first meeting of teaching Tenses by using TST (Tenses Symbols Technique). The lesson plan consists of the subject matter to be taught, the standard of competence to be achieved, the aims of teaching that are based on the indicators of Tenses mastery, the media used, the technique to be employed; in this case is TST, the steps of teaching and learning process; Memorizing the 12 tenses, Formulating the pattern, Understanding the usage, and Applying the formulas in context, the closing procedure, and at last the evaluation task.

This lesson plan was, then, acted in the classroom and during the 
teaching learning process. It was the 2nd semester of class X4 of the academic year of 2015-2016 in SMAN 1 Pekanbaru. The researcher started the class with some opening activities like praying, greeting, and taking attendance of the class in about 5 minutes. Warming up activity, then, was done by asking the students about how far they know the 12 tenses in English. The teacher asked; "Do you know tenses in English?" "Yeees...?" students answered in chorus. The teacher then asked, "How many tenses do you know?" some said 12, others said 16. When the teacher asked three names of the tenses, nobody could answer correctlly; the answers such as simple perfect, present past, or continous simple filled out the air. It showed that the students' background knowledge about tenses is very minimal.

And then, the teacher asked again, "Do you think that studying tenses is difficult?" A student said that it is the most difficult subject since he had English lesson. And the teacher said that she would introduce a new way to master it. The teacher asked the students to keep away all the notes and only focused on her and what she said because the activity of drilling would be began.

It was started by displaying the symbols of basic tenses; Past, Present, and Future. The teacher mentioned the names of the three symbols and the students repeated. It was easily mastered, nobody could not answer when they were asked to mention the name of the symbols one by one. After several drillings, the teacher moved to the aspect symbos; Simple, Continous, Perfect, and Perfect Continous. With the same way, teacher displayed the symbols, mentioned the names, and asked students to repeat. During the activity of drilling, students were very enthusiastic to repeat what the teacher mentioned and the process of decoding was successfully done.

\subsection{The Findings}

The participants/subjects of this research are the students of the second semester of class $X$ at SMAN 1 Pekanbaru. There are 33 students in this class who will be investigated. This is the class in which the problems has been identified and need solutions.

The test was used to measure the tenses mastery of the students in this research is writing test especially in the applying the tenses step (the fourth step). The writing test is assumed more suitable since the grammar rules are applied mostly in written text.

Tenses mastery is the stuff tested in this research that covers the mastery of the twelve tenses in English; The Present Tenses are; Simple Present, Present Continous, Present Perfect, and Present Perfect Continous, The Past Tenses are simple past, Past Continous, Past Perfect, and Past Perfect Continous, and The Future Tenses are Simple Future, Future Continous, Future Perect and Future Perfect Continous. While the combination of Perfect and Continous, we have Present perfect continous, Past perfect continous, and Future Perfect continous.

The indicators used is as suggested by Nunan (2003) that tenses mastered if the students are able to memorize, understand, and 
apply the tenses rules in their communicative activities.

As stated above, there was significant increase of students' score in cycle 2 after some improvement in planning and acting stages. The result of the tests in every steps of TST showed that students were able to memorize the name of the tenses as well as the formula, they were able to understand the tenses, and they were able to apply the formula in context. The result of students' score as follow;

Figure 1. students' tenses mastery in cycle 1

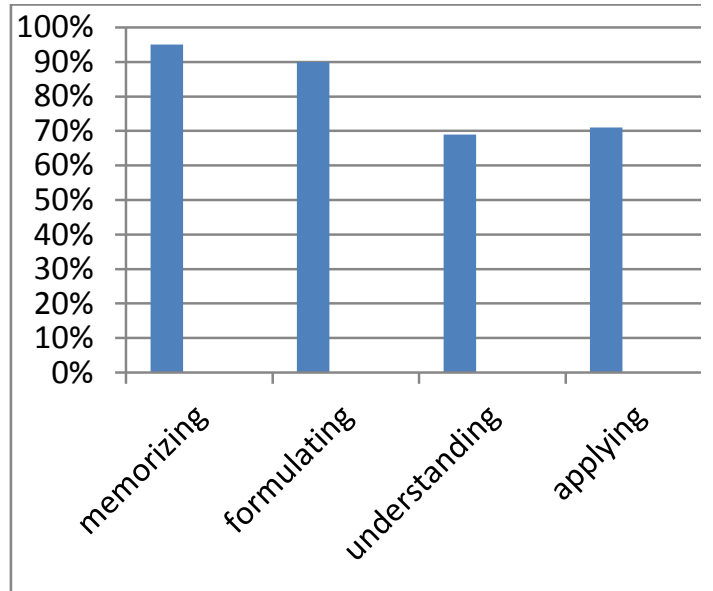

Comparing the result in cycle 1 and in cycle 2 there was increase in about $14 \%$. It might be caused by the reinforcement done by the teacher so that students became more understand about the usage of the tenses. The comparison can be seen in the following graph;
Figure 2. the graph of students' improvement in cycle 2

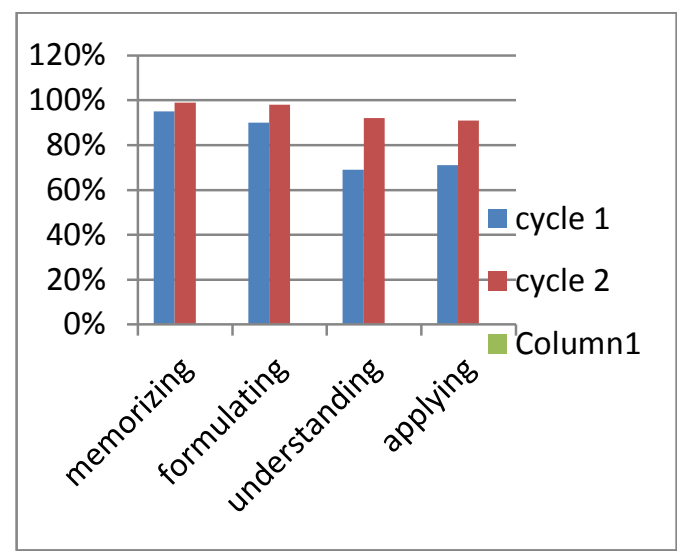

The research of investigating whether Tenses Symbol Technique (TST) found by the researcher is effective to solve the students' difficulties in memorizing the names of the tenses and the formula and to what extent does TST improve the students' tenses mastery has found the answer that by analyzing the data taken from the observation check-lists, tests, field notes, and interviews, it is very obvious that TST improved the tenses mastery of the students of class X4 in SMAN1 Pekanbaru.

The improvement occured because TST has promoted the use of symbols to stimulate students' ability to remember information in long term memory. It is in line with what Deacon, T.W. (1997) argued that human is called a symbolic species, that the use of symbols was as old as the history of human itself. It is also known that it is much easier for human being to recognize symbols than words that symbols are used in vast areas of human life. In brief, TST has effectively worked to improved students' tenses mastery that for so long has been the troublesome in many English classes. 
TST as a new technique certainly has many weaknesses even this research is also not so valid to proof its effectiveness. The weaknesses might be on the theories supporting it or the way this research was handled, and so on. So, the next researches are badly needed in order to get more advantages from this technique.

This is due to the thought that tenses mastery in EFL class can help teachers and students to be skilful in the four major skills of writing, speaking, reading, and listening. There is also no objection that tenses mastery is very important to master English grammar as a whole that most English structured language are produced by the knowledge of tenses.

\section{CONCLUSION}

Student's Tenses mastery is an important competence to support the major English skills, listening, speaking, reading, and writing. Beside, the tenses mastery is also important to have another grammar materials that need Tenses mastery as the basic knowledge.

However, in reality, students' tenses mastery is very minimal that they are not able to call out the names of the tenses, mention the formulas, let alone to understand meaning and the usage in sentences. To solve this problem the resercher has created a teaching technique, namely, Tenses Symbols Technique (TST) that covers four steps of tenses mastery: memorizing tenses names, formulating tenses patterns, understanding tenses meanings, dan applying in context.
As the conclusion of this research paper is Tenses Symbols Technique (TST) is effective to improve the tenses mastery of the students of class X4 of SMAN 1 Pekanbaru. It is shown by the qualitative and quantitative data got during the action research. It is also concluded that the use of symbols in TST is appropriate to the nature of human as the symbolic species that the symbols can be remembered long lasting than words. It is to answer to what extent does TST improve students' tenses mastery.

\section{Implications}

Based on the conclusion above it is said that TST is recomended to be one of the technique to master English tenses in EFL classes in Indonesia. This has been tested to my students of class X4 of SMAN 1 Pekanbaru that significant increase of students' score in many forms of tasks testing their tenses knowledge has been made. And I believe this will also happen in other classes applying it.

\section{Suggestion}

TST would be more effective if in applying it, for the first time avoid using any notes or other recording tools because in the step 1 of memorizing names and step 2 of formulating students only focus on the drill. The drill done by the teacher should be repeated by the students loudly that speaking aloud can raise spirit among students. To make students understand the meaning of each tenses, it's better for the teacher to reinforce by a bit explanation so that students can use tenses in vary of context. 


\section{REFERENCES}

Corballis, M.C. (1999) The gestural origins of language. Am. Sci. 87, 138-145

Deacon, T.W. (1997) The Symbolic Species: The Co-Evolution of Language and the Brain, Norton

Gay. L. R. and Peter Airasian. 2000. Educational Research: Competencies for Analysis and Application $\left(6^{\text {th }}\right.$ ed.) Saddle River, New Jersey. Prentice Hall.

Gokhale, Madhuri. (2010). Research Paper: „A Pragmatic Approach to the Teaching of Grammar in Indian Context". Elt Weekly, Vol. 2 Issue 75 November http://eltweekly.com ISSN 0975-3036

Graver, B.D. (1986). Advanced English Practice. Oxford: Oxford University Press.

Harmer, J. How to Teach English: An Introduction to the Practice of English Language Teaching. Essex, Pearson Education Limited, 2007.

Kemmis. S. and Taggart. R. 1999. The Action Research Planner. Deakin University Press.

Madya. Suwarsih. 2007. Teori dan Praktik Penelitian Tindakan.Action Research. Alfabeta Bandung.

Nunan, D., Practical English Language Teaching, McGrawHill, New York, 2003.

Radford, L. (2000) Signs and meanings in students'emergent algebraic thinking: a semiotic analysis. Educational studies in mathematics, 42: 237-268.
Robotti, E. (2002) Functions of natural language in the resolution of a plane geometry problem, Institutoper le Tecnologie Didattiche-CNR of Genova; University of Genova.

Salomon, G. (1979). Interaction of Media, Cognition, and Learning. San Fransisco: Jossey-Bass.

Sidney Greenbaum and Randolph Quirk, Students' Grammar of the English Language, London : Pearson Education Limited, 1990

Thornbury, S., How to Teach Grammar. Pearson Education Limited, Malaysia, 2002.

Ur, P., Grammar Practice Activities: A Practical Guide for Teacher, Cambridge University Press, Cambridge, 2006.

Uttal, D.H. et al. (1999) Taking a hard look at concreteness: do real objects help children learn? In Child Psychology: A Handbook of Contemporary Issues (Tamis-LeMonda, C. and Balter, L., eds),pp. 177-192, Garland, Hamden Connecticut 